\title{
SPROUTING, GROWTH CHARACTERISTICS AND YIELD OF PEAS PLANT (PISUM SATIVUM) ON VARIOUS WATER IRRIGATION
}

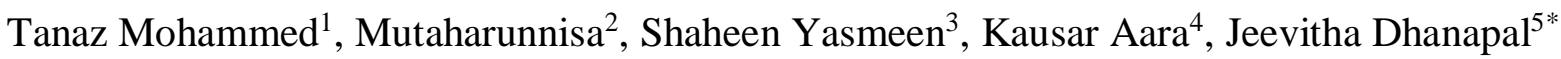 \\ ${ }^{1,3}$ Centennial Elementary School, Lubbock, Texas - 79416, U.S.A. \\ ${ }^{2}$ Vivekavardhini Junior College, Kothagudem - 507123, Telangana, India \\ ${ }^{4}$ Merit Degree College, Yellandu - 507123, Telangana, India \\ ${ }^{5 *}$ Labmate Asia Pvt. Ltd., Mount Road, Chennai - 600015, Tamilnadu, India \\ *Corresponding Author
}

DOI: https://doi.org/10.51193/IJAER.2021.7203

\begin{abstract}
The requirement for better yielding with inexpensive capitals will become progressively significant in the agronomic ecosystem. Many researches have been validated the water management hydroponic system if appropriate organization is conserved, thus preservation and checking of water characteristic factors are critical for effective plants development. There are many in-house experiments on sprouting peas but the published articles are very limited. As the result of their palatability and nutritional properties, the interest in pea sprouts as a super food is growing rapidly. The potential microbiological risks however, are challenging producers in finding innovative ways to ensure the safety of the product without compromising the quality. One of the ways to achieve this is to employ water rich in minerals for sprout production process. The aim of this work was to evaluate the growth and its characteristics and yield of peas plant. Pea seeds were chosen to soak and sprout in various types of water in laboratory environment for 7 days. The results established that, seeds irrigated with mineral rich water was longer, healthier and produces more yield compared to the seeds with other waters. It proves irrigating water is essential for growth of plants with complete minerals and exclusive of organisms.
\end{abstract}

Keywords: Mineral, Peas, Sprouting, Water 
International Journal of Agriculture and Environmental Research

ISSN: 2455-6939

Volume: 07, Issue: 02 "March-April 2021"

\section{INTRODUCTION}

World population has been estimated to surpass 9.6 billion people by the year 2050. Food supply, farmers and food processing industry and related partners will bear a huge stress for feeding the near 10 billion individuals (Goddek, 2015). The importance of attaining creative solutions to produce more food from limited land will be increasing. This includes production methods that are 'soil-less' (not traditional in-ground). Food production society can be a more beneficial, environmentally-friendly, business-minded and technological society by adopting urban agriculture innovation although the research and technology on alternative crop production methods are less confined (Eatmon, 2014). To eliminate or reduce the numbers of pathogens on fresh produce, proper Good Manufacturing Practices and processing techniques are required (Beuchat, 1996).

The FAO defines pulses as legumes solely harvested for their directly consumable seeds. The oilseed legumes and those consumed in immature form as vegetables have been excluded by the FAO and the FAO list includes eleven primary pulses (FAO, 1994). The pea has been known since antiquity and probably originated in Abyssinia and Afghanistan earlier, and the colonized regions of Mediterranean later. From these parts, the pea spread to other parts of Europe and Asia. In Arthur Hort's English translated book 'Enquiry into plants' written by Theophrastus (1961), mentions traces of pea much earlier than 300 years B.C. He describes several species of legumes especially the 'Pea' and reveals that peas were used for fodder and human food. The pea was the prehistoric age crop that was known in Europe. The yellow or green cotyledon varieties of peas known as dry, smooth or field peas, are the naturally dried seeds of Pisumsativum L. They are grown around the world for human and animal consumption. The major producers of peas being Canada, the Russian Federation, China, the USA and India and the World production crossed Ten million tonnes (FAO, 2011). Peas have long been categorized as an inexpensive, readily available source of protein, complex carbohydrates, vitamins and minerals. The peas are the valuable food commodity, due to their high nutrient density which is adequate for dietary needs of the estimated 800-900 million malnourished individuals worldwide (FAO, 2011) A solely a soil-less method termed as hydroponic system is using only water and chemical nutrients (Resh, 2012). The system of aquaponics does not require soil for crop production as same as the method of hydroponics (Bernstein, 2012). The plant's roots being soaked in an oxygenated and nutrient-rich water supply in aquaponics and hydroponics techniques (Goddek, 2015). Much of North American continent's greenhouse tomato, basil, and lettuce production is primarily done with a hydroponic growing technique (Bernstein, 2012). 
International Journal of Agriculture and Environmental Research

ISSN: 2455-6939

Volume: 07, Issue: 02 "March-April 2021"

For the survival of every plant in the world, water is a vital component which aids the way they obtain their food (through the process of photosynthesis), grow (cell division, mitosis), respire (cellular respiration) and how they keep their formation (rigidity). Formation of plants are maintained by the help of water as the water is transporting dissolved nutrients, amino acids and sugars from the soil to areas where it is of high demand. It flows through cell membranes from a high concentrated area of to a low concentrated area (osmosis) (Lodish et al, 2000).

The quantity of water absorbed by land plants and transpired to the atmosphere is $32 \times 10^{15} \mathrm{~kg}$ year ${ }^{-1}$ roughly, but it is about $120 \times 10^{15} \mathrm{~g}$ of carbon annually by terrestrial photosynthesis (Schimel et al., 2001). For the recent changes in continental runoff and freshwater availability associated with the global rise in $\mathrm{CO}_{2}$, stomatal transpiration by plants is tentatively believed to have made a significant contribution (Gedney et al., 2006), although the consequences of other human activities, especially land use had to be weighed against the plants (Piao et al., 2007). This article focuses the importance of water irrigation on peas sprouting in terms of growth characteristics.

\section{MATERIALS}

Dried peas seed were purchased from the local market. Seeds were washed and spread evenly in the cheese cloth of polystyrene trays. Tap water and reverse osmosis (RO) water from home supply, distilled water with the brand name Great Value purchased from Walmart, Lake water taken from Maxey Park, and Mineral water with the brand name Nestle, purchased from local market.

\section{METHOD}

\section{Sprouting}

This experiment was carried for 7 days. 5 different sources of water (distilled, tap, mineral, RO and lake waters) were used to grow dried peas sprouts. All seeds were placed in identical separate plates ( $40 \mathrm{~cm}$ long $\times 31.8 \mathrm{~cm}$ wide $\times 15.2 \mathrm{~cm}$ deep) on a three-layered folded cheese cloth that was previously sprayed with $100 \mathrm{~mL}$ of the designated water. The seeds were sprinkled evenly by hand and were appropriately labelled based on treatment. There were a total of five plates and all were covered with linen cloth. The sprouts were watered twice daily with approximately $100 \mathrm{~mL}$ of designated water. The temperature, relative humidity, and time at the lab were recorded daily. 
International Journal of Agriculture and Environmental Research

ISSN: 2455-6939

Volume: 07, Issue: 02 "March-April 2021"

\section{Growth Parameters}

A total of 10 random seeds were selected for weighing on the day of planting. The sprouts growth parameters were measured daily using a caliper starting at Day 0 ( $1^{\text {st }}$ day) and ending on Day 6 ( $7^{\text {th }}$ day). A total of 5 sprouts from the different treated plates were randomly selected for physical measurement daily; however, to get the best representation of the entire growing plate, the pattern of choosing sprouts along the edges of the plate and in the middle were maintained for each recording. The length of the root, stem, whole length of the plant was observed in millimeters and recorded. Other observations included yield of the plant also recorded.

The 5 randomly selected sprouts were plucked by hand from the cheese cloth and placed on a clean moisten paper towel in prep for measurement. The towel was moist to ensure that the root of the sprout did not shrivel which would make measuring difficult. If part of the plant appeared broken or showed signs of deterioration, the plant was discarded and another sample was obtained. The sprouts were held by hand for stem, and root length. The sprout was then straightened on a paper towel for the caliper to obtain length of the stem, length of the root, and whole length of the plant. After the measurements were recorded, the selected sprouts were then discarded. This was repeated for all the treatments. On the last day, the sprouts were harvested by hand and were divided out for physical measurement. Wearing latex gloves and simply plucking the sprout by the stem ensured that the root was fully intact during harvesting. Again, if any damage occurred, the plant was discarded and a new sample was obtained. Five randomly selected sprouts were set aside for physical measurements. Two sets of 5 sprouts were obtained from each treatment for weight measurements. The first sets of 5 weights were recorded and then the second set was added on the analytical balance and recorded as "weight of 10 sprouts".

\section{RESULTS AND DISCUSSION}

Pea sprouts reached maturity in all the tested waters after seven days of growth (Day 0 to 6). This is the typical growth pattern for pea sprout (USDA, 2002). Each type of water had the typical growth pattern commonly observed for sprouts without retardation. This study evaluates the root, stem, whole length and yield of peas plant.

\section{Growth Characteristics of the peas}

Root length of peas grown in 5 types of water was observed and it was recorded in millimetre $(\mathrm{mm})$. There was no root formation in Day 0 ( $1^{\text {st }}$ day) in any water types. In Day 1 ( $2^{\text {nd }}$ day), roots formation was observed in lake, mineral, RO and tap waters, but no root was seen in distilled water. The root length measured in lake, mineral, RO and tap waters are 3.5, 4.6, 0.2, 
and $3.1 \mathrm{~mm}$ respectively. From Day $2\left(3^{\text {rd }}\right.$ day) to 6 ( $7^{\text {th }}$ day), roots were grown gradually in all types of waters. Roots length in distilled water were ranging from 0.4 to $3.1 \mathrm{~mm}$, lake water ranging from 6.4 to $27.2 \mathrm{~mm}$, mineral water ranging from 7.3 to $28.2 \mathrm{~mm}$, RO ranging from 11.1 to $9.7 \mathrm{~mm}$ and tap water from 5.9 to $22.1 \mathrm{~mm}$ respectively (Fig. $1 \mathrm{a}$ ). In all types of water there were a transition from seeds to sprouts from Day 2 of production as evidenced by roots appeared more sprout-like when they had shed the seed coat. Roots are the essential part for delivering dissolved elements and nutrients to the stem and leaves (Furman University, 2016). According to Whiting, the primary root will initiate to attain sub-division of roots that are sustained by photosynthesis from the shoots of the sprouts in order to obtain enough nutrients. Consequently, branched roots are a solid proof that the sprouts are having a wealthy development and are needing extra nutrients (Whiting, 2003).

Fig. 1: Peas growth was measured from Day 0 to Day 6 and recorded in mm (a) Root length (b) Stem length (c) whole length

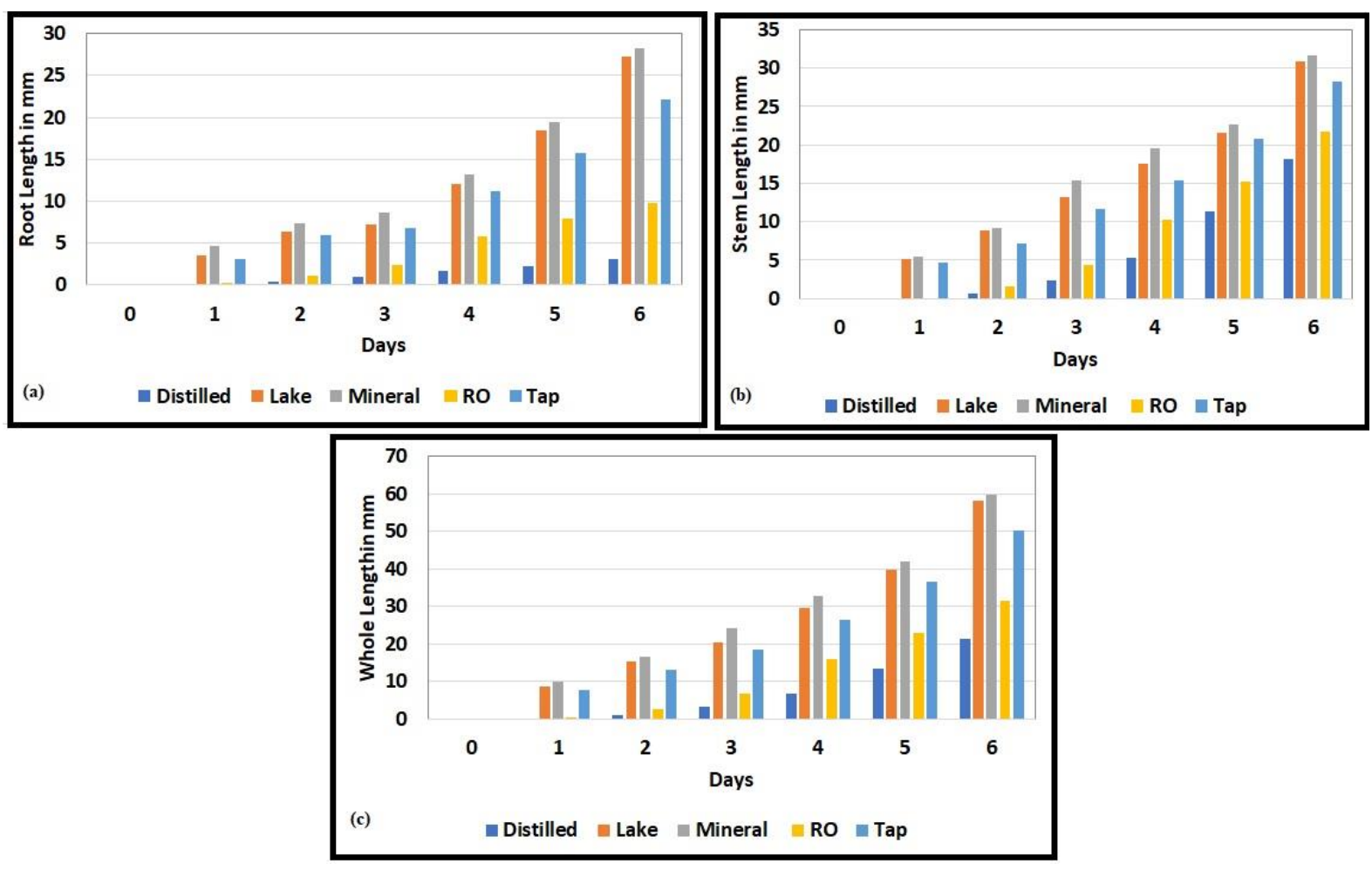

The stem length was experimented when there is a color variation seen between seed and the start of the root of the plant. When the seeds primarily budded in the water, the early disruption from the seed was deliberated the root of the plant. When the plant started growing upward, and this portion of the plant was contemplated the stem described as emerging as a white thin part of 
International Journal of Agriculture and Environmental Research

ISSN: 2455-6939

Volume: 07, Issue: 02 "March-April 2021"

the alfalfa sprout (Biology Discussion, 2013). With this specific type of sprout, stems seem as a thin white stalk (Colorado Integrated Food Safety, 2015). Stem length of peas grown in 5 types of water was observed and recorded in $\mathrm{mm}$. There was no root formation in Day $0\left(1^{\text {st }}\right.$ day) in any water types. From day 1 there was a stem development in the peas grown in lake, mineral and tap waters, but no stem growth in RO and distilled water. At Day 1, stem growth in mineral, lake and tap waters ranging from 5.5, 5.1 and $4.7 \mathrm{~mm}$ respectively. From Day 2 stem growth was observed in all types of waters. Each day there was a gradual increase in stem growth. The distilled water range varies from 0.7 to $18.2 \mathrm{~mm}$, lake water ranging 8.9 to $30.9 \mathrm{~mm}$, mineral water from 9.2 to $31.7 \mathrm{~mm}, \mathrm{RO}$ and tap waters ranging from 1.5 to $21.8 \mathrm{~mm}$ and 7.2 to $28.2 \mathrm{~mm}$ respectively (Fig. 1b). The home grown alfalfa sprouts will typically have longer stem lengths that added to the majority of the whole length of the sprout, which is $2.5-3.8 \mathrm{~cm}$ (Bouton, 1996). The two green leaves will arise from the stem of a conventionally full-grown sprout, compelling the place of the seed. The home grown sprouts will contain a thin stem with two small leaves; but, with the greenhouse systems a third leaf was observed between the two leaves closer to harvest. (Belabre, 2015).

The whole length of the peas was also measured and recorded in mm (Fig. $1 \mathrm{c}$ ). There was a steady growth in root and stem length of the peas in all types of water. However, there was a slow growth in distilled and RO waters. Though there were certain conclusions by observing the root, stem length of the peas plant grown in mineral, lake, tap, distilled and RO waters, still further observation was done to conclude this study. Finally yield of the peas was weighed and recorded in grams.

Weights of sprouts was measured at Day 0 and Day 6, there were no difference in any types of water at Day 0. However, the peas plant harvested at day 6 in distilled, lake, mineral, RO and tap waters weighed of 1.2, 4.6, 6.8, 2.4, and 3.1 grams respectively. Silva et al, 2015 also observed the yield difference with weights among traditional grown systems against aquaponic (Silva et al., 2015; Hu et al., 2015). The marketable principles set and the only requirement by the U.S. Department of Agriculture, is that the quality of the sprouts should be fleshy, tender, and crunchy and in somewhat off-white color, and there is no set average weight for fresh bean sprouts. The reports about harvest shows that half a cup of seed should produce half pound of sprouts (Sprout People, 2016; USDA, 2015). The only evidence about required weights for sprouts is that 2 tablespoons of seed should produce half pound of sprouts (Sprout People, 2016). Distilled water is one of the purified and demineralised water and its experimentations in humans discovered that demineralised water augmented diuresis and the removal of electrolytes, with reduced serum potassium absorption. Magnesium, calcium, and other nutrients in water can help to protect against nutritional deficiency. RO water is also a demineralized water that is deficient in essential minerals like sodium, potassium, calcium, magnesium and other important dissolved 
solids. This might be reason of slow growth and less yield in distilled and RO waters which also an important constituent for peas growth.

\section{CONCLUSION}

All the physical parameters (length of the root, stem and whole length) were found to be different in all types of water tested. Especially, mineral water has shown very good growth. The variations could only due to water irrigation provided to the sprouts with minerals, as all the ecological aspects for the development of seed to plants were detained persistent. Apart from sprouting and characteristics, there was a huge difference in yield among waters tested. This may have been the outcome of having an enough amount of minerals in the mineral water than other water types. Results from this study indicated that minerals are essential constituent of all living organisms and it's important for peas growth and yield.

\section{REFERENCES}

Goddek, S, Delaide, B, Mankasingh, U, Ragnarsdottir, K, Jijakli, H, Thorarinsdottir, R. 2015. Challenges of sustainable and commercial aquaponics. Sustainability 7 (4) 4199-4224.

Eatmon, T. 2014. Aquaponic food production as an integrating context for campus sustainability: a review. AASHE Association for the Advancement of Sustainability in Higher Education. Available from: http://www.aashe.org/resources/case-studies/aquaponic-foodproduction- integrating-context-campus-sustainability.

Beuchat, LR. 1996. Pathogenic microorganisms associated with fresh produce. Journal of Food Protection. 59 (2): 204-216.

Food and Agriculture Organization (1994) Definition and classification of commodities: pulses and derived products. http://www.fao.org/es/faodef/fdef04e.htm (accessed Octo- ber 2011).

Food and Agriculture Organization (2011) FAOSTAT. http:// faostat.fao.org (accessed July 2011).

Food and Agriculture Organization (2011) FAO Statisitics. Food Security Data and Definitions 2005-2007. Food Depri- vation. Number of Undernourished Persons. http://www.fao.org/ economic/ess/ess-fs/fs-data/ess-fadata/en/ (accessed June 2011). 
International Journal of Agriculture and Environmental Research

ISSN: 2455-6939

Volume: 07, Issue: 02 "March-April 2021"

Resh, H.M. Hydroponic Food Production: A definitive guidebook for the advanced home gardener and the commercial hydroponic grower. CRC Press: Boca Raton, FL, USA, 2012.

Bernstein, S. Chapter 2: The global Perspective. In: Sylvia Bernstein: Aquaponic Gardening. 2012. 1-37.

Goddek, S, Delaide, B, Mankasingh, U, Ragnarsdottir, K, Jijakli, H, Thorarinsdottir, R. 2015. Challenges of sustainable and commercial aquaponics. Sustainability 7 (4) 4199-4224.

Lodish H, Berk A, Zipursky SL, et al. Osmosis, Water Channels, and the Regulation of Cell Volume, New York: W. H. Freeman; 2000, Molecular Cell Biology. 4th edition.

Schimel DS, House JI, Hibbard KA, Bousquet P, Ciais P, Peylin P, Braswell BH, Apps MJ, Baker D, Bondeau A, et al. (2001) Recent patterns and mechanisms of carbon exchange by terrestrial ecosystems. Nature 414: 169-172

Gedney N, Cox PM, Betts RA, Boucher O, Huntingford C, Stott PA. (2006) Detection of a direct carbon dioxide effect in continental river runoff records. Nature 439: 835-838

Piao S, Friedlingstein P, Ciais P, de Noblet-Ducoudré N, Labat D, Zaehle S. (2007) Changes in climate and land use have a larger direct impact than rising $\mathrm{CO}_{2}$ on global river runoff trends. ProcNatlAcadSci USA 104: 15242-15247

Furman University. 2016. Plant Roots. Accessed on 17 June 2016. Available from: http://facweb.furman.edu/ lthompson/bgy34/plantanatomy/plant_root.htm

Whiting, D., Roll, M., Vickerman, L.2003. Plant Structure: Roots. CMG Garden Notes from Colorado State University Extension. Accessed on 16 June 2016.

Biology Discussion. 2016. Seed Germination Types (With Diagram). Accessed on 6 Jun 2016. Available from: http://www.biologydiscussion.com/seed/germination/seed-germinationtypes- with-diagram/15789

Colorado Integrated Food Safety Center of Excellence. 2015. Sprouts. Accessed on: 23 Nov. 2015 Available from: http://fsi.colostate.edu/tag/vegetables/ 
Bouton, J. 1996. New Uses for Alfalfa and Other “Old” Forage Legumes. P 251 - 259. I: J. Janick (ed.), Progress in new crops. ASHS Press, Alexandria, VA.

Belabre, B., Dekevich, D., Dement, J. 2015. Sprouts. Fort Collins, CO: Food Source Information Colorado State University. Available from: www.fsi.colostate.edu/sprouts/. Accessed March 17, 2015.

Silva, L., Gasca-Leyva, E., Escalante, E., Fitzsimmons, K., and Lozano, D. 2015. Evaluation of biomass yield and water treatment in two aquaponic systems using the dynamic root float technique (DRF). Journal of Sustainability. 7(11): 15384- 399

Hu, Z, Woo Lee, J, Chandran, K, Kim, S, Brotto, AC, Khanal, SK. 2014. Effect of plant species on nitrogen recovery in aquaponics. Journal of Bioresource Technology 188 (2015) 9298.

Sprout People. 2016. Growing Sprouts. Accessed 3 June 2016. Available from: https://sproutpeople.org/growing-mung-bean-sprouts/

U.S. Food and Drug Administration (FDA). 2015. Sprout Safety Alliance. Silver Spring, MD: FDA. Accessed 9 June 2016. Available from: http://www.fda.gov/Food/GuidanceRegulation/FSMA/ucm293429.htm 